\title{
Digenean metacercariae parasites as natural tags of habitat use by 0 - group common sole Solea solea in nearshore coastal areas: A case study in the embayed system of the Pertuis Charentais (Bay of Biscay, France)
}

\author{
Eric D.H. Durieux ${ }^{a}{ }^{*}$, Marie-Laure Bégout ${ }^{\mathrm{a}}$, Patrick Pinet $^{\mathrm{a}}$ and Pierre Sasal ${ }^{\mathrm{b}, \mathrm{c}}$
}

\begin{abstract}
a IFREMER, Laboratoire Ressources Halieutiques, Place du Séminaire, BP5, 17137 L'Houmeau, France
${ }^{b}$ Laboratoire de Biologie et d'Ecologie Tropicale et Méditerranéenne, UMR 5244 CNRS-EPHE-UPVD, Université de Perpignan Via Domitia, 52 Avenue Paul Alduy, 66860 Perpignan, France

c UMS 2978 CNRS-EPHE, CRIOBE, BP 1013 Moorea, French Polynesia
\end{abstract}

*: Corresponding author : Eric D.H. Durieux, email address : edh.durieux@gmail.com

\begin{abstract}
:
This study focused on the spatio-temporal variation in the host-parasite system, 0-group soledigenean metacercariae, in nearshore coastal areas at relatively small spatial scale. 0-group soles were sampled using a standard beam trawl in April, May, June, August and October 2005 at nine different sites in the Pertuis Charentais area (Bay of Biscay, France). Sole density, size, Fulton's condition factor $K$ and digenean metacercariae communities were analysed. 0-group sole concentrated in shallow and muddy areas where they accumulated digenean metacercariae. Parasite communities displayed strong spatial patterns tightly linked to the distribution of the first intermediate mollusc hosts. These parasitological data suggest that 0-group sole during their first period of growth are mainly sedentary with limited movements between the different parts of the habitat. Size and density data revealed spatial heterogeneity in terms of habitat quality so that a limited zone (Aiguillon Bay) within the study area could be identified as sensu stricto nursery habitat for 0-group sole. The use of digenean metacercariae as natural tags appears as a novel powerful tool to evaluate habitat use and movements of juvenile flatfish, which could find applications in fisheries and coastal zone management programs.
\end{abstract}

Keywords: Flatfish; Juveniles; Trematodes; Parasite Community; Spatio-temporal Dynamics; Habitat Use 


\section{Introduction}

Coastal areas are highly productive ecosystems that are essential habitats for the juveniles of many marine fishes and especially flatfishes. However, these habitats display highly variable natural environmental conditions to which often superimpose anthropogenic disturbances of various origins. As a consequence, on a spatial basis and for a given species, juvenile habitat quantity and quality appear highly variable (Beck et al., 2001; Dahlgren et al., 2006). In order to achieve habitat conservation and sustainable management of fisheries, it is therefore critical to understand fish juveniles spatio-temporal dynamics within these coastal habitats (Rice, 2005).

Different methods exist to study fish spatio-temporal dynamics: i) distributions based on capture data (e.g. occurrence, abundance and size structure); ii) use of artificial tags (e.g. conventional tags, acoustic tags and archival tags); iii) use of genetic markers (e.g. microsatellites, RAPD, mitochondrial DNA); and finally iv) use of natural tags (e.g. otolith microchemistry and shape, stable isotopes, parasites). Each of these methods has its own spatio-temporal resolution range with advantages and limitations in terms of sampling representativity, effort, logistics, analysis time, price, etc. However, among them, the use of natural tags appear often as a good compromise and they are especially well suited to study the movements of fish juveniles within and between different coastal habitats (Gillanders et al., 2003).

Parasites are a natural part of all ecosystems and play an important role in their functioning especially in shallow coastal areas where they represent a key component of the biodiversity (Combes, 2001). Among natural tags, parasites have an extensive history of use in fish population studies (MacKenzie, 2005). The basic principle 
underlying the use of parasites as tags is that fish can become infected with a parasite only when they come within the area suitable for the transmission of that specific parasite (MacKenzie, 2005). Based on these characteristics, parasites have been used mainly at large spatial scale (hundreds of kilometres) to evaluate migratory routes or to discriminate stock in fish population. Very few studies have used parasites at a smaller spatial scale (hundreds of meters to few kilometres) and that was essentially to study fish connectivity between inshore and offshore habitats (Olson and Pratt, 1973; Sujatha and Madhavi, 1990; Vignon et al., 2008).

On coastal nursery grounds, 0-group flatfish juveniles become infected especially with digenean metacercariae parasites (El-Darsh and Whitfield, 1999; Durieux et al., 2007a). Like many internal parasites, digeneans have a complex life cycle with molluscs as first intermediate hosts, invertebrates and small fishes as second intermediate hosts and vertebrate predators (such as fishes, birds or mammals) as definitive hosts . Cercariae are digeneans' larval stage that are produced in quantity in the mollusc first intermediate host; once developed, cercariae are expelled from the molluscs into the water column; then after locating the second intermediate host, they actively penetrate through the skin, encyst as metacercariae in the body and transmission to the definitive host occurs through predation upon the second intermediate host. Based on these biological characteristics, digenean metacercariae appear promising natural tags to study habitat use of juvenile flatfish acting as second intermediate hosts.

The common sole Solea solea (L.) is a widely distributed and economically important flatfish of the North East Atlantic and Mediterranean Sea. As most of commercial demersal species in this region it is also reported as over-exploited for most stocks 
(ICES, 2005). After a planktonic larval stage, 0-group sole juveniles colonize and settle in discrete shallow soft bottom coastal habitats such as estuaries, bays, lagoons or sandy beaches (Amara et al., 2000). During the first growing season 0-group sole are especially sensitive to both natural and anthropogenic stressors exhibited in these areas, which imply variability in their biological performances and survival and in fine can influence adult stock recruitment. Therefore a number of studies have focused on 0group sole habitat suitability (Eastwood et al., 2003; Le Pape et al., 2003b; Le Pape et al., 2007) and quality (Gilliers et al., 2006; Amara et al., 2007; Vinagre et al., 2008b). As results of these studies, the main factors characterising the habitat and influencing its quality have been identified. However there is still a clear need to estimate habitat use and movement capacities of 0 -group sole to define the connectivity within the mosaic of habitats that constitutes coastal areas in order to better understand the functionality of each habitat at small spatial scale.

In the present case study, we propose a novel approach using digenean metacercariae as natural tags to estimate habitat use and movements of 0-group sole in nearshore coastal areas at relatively small spatial scale. The aims of this study were to: i) evaluate the spatio-temporal change in 0-group sole density through the first growing season within the Pertuis Charentais (France), one of the main area for sole juveniles in the Bay of Biscay; ii) evaluate the spatio-temporal change in digenean metacercariae infection of 0-group sole; iii) test the use digenean metacercariae as natural tags to determine movements and habitat use of 0-group sole in the study area; and finally iv) estimate habitat quality based on fish size and body condition in the study area.

\section{Material and methods}




\subsection{Study area}

The Pertuis Charentais are located on the French Atlantic coast (Bay of Biscay) north of the Gironde estuary (Fig. 1). This area is an embayment complex constituted by two main straits (Pertuis Breton and Pertuis d'Antioche) with a total surface area of 1300 $\mathrm{km}^{2}$ comprising $340 \mathrm{~km}^{2}$ of shallow (0-5m depth) soft bottom areas essentially located in the inner bays and north of the Pertuis Breton close to the mainland. The substrate of these large shallow soft areas is essentially muddy but the north of the Pertuis Breton, that is constituted of thin sand. The Pertuis Charentais area is considered as the largest suitable habitat for 0-group sole in the Bay of Biscay (Le Pape et al., 2003b). This macrotidal area is largely characterised by a marine water influence. Only small rivers flow into each strait (average annual river-flow of 5, 10, 50 and $10 \mathrm{~m}^{3} \mathrm{~s}^{-1}$ for the Le Lay, Sèvre Niortaise, the Charente and Seudre Rivers, respectively). The tidal range is $6.4 \mathrm{~m}$ and the average tidal current is $0.5 \mathrm{~m} \mathrm{~s}^{-1}$ during spring tides, which generates rapid renewal of marine water and well-mixed environment, particularly in the shallowest areas. In addition, most intertidal areas that are suitable for 0-group sole are used for the cultivation of Pacific oyster (Europe's largest production area) and mussel with estimated standing stock of 125,000 and 20,000 tons respectively in 2001 (Goulletquer and Le Moine, 2002).

\subsection{Fish sampling and parasite collection}

0-group soles were sampled using a standard beam trawl ( $2 \mathrm{~m}$ wide, $0.4 \mathrm{~m}$ high, mounted with a $5 \mathrm{~mm}$ stretched mesh net in the cod end) at 2.5 knots for $20 \mathrm{~min} .0$ group sole were sampled in April $\left(21^{\text {st }}\right.$ and $\left.28^{\text {th }}\right)$, May $\left(23^{\text {rd }}\right.$ and $\left.24^{\text {th }}\right)$, June $\left(27^{\text {th }}\right.$ and $\left.28^{\text {th }}\right)$, August $\left(9^{\text {th }}\right.$ and $\left.10^{\text {th }}\right)$ and October $\left(4^{\text {th }}\right.$ and $\left.5^{\text {th }}\right) 2005$ in the Pertuis Charentais on seven sites located in shallow areas $(0-5 \mathrm{~m})$ and two sites (one per strait) located in 
deeper areas (5-10 m) (Fig. 1). All sites were located on muddy bottom but sites PB1 and PB2 were located on sandy bottom. Directly after catch, fish were placed on ice, so that at the laboratory 0-group soles were counted, measured for standard length (SL to nearest $\mathrm{mm})$ and weighed $\left(\mathrm{M}_{\mathrm{W}}\right.$ to the nearest $\left.0.01 \mathrm{~g}\right)$. We used a nested sampling design with up to 120 individuals per month/site randomly selected for SL measurement and, within this sample, up to 30 individuals randomly subsampled for $\mathrm{M}_{\mathrm{W}}$ measurement. For parasite analysis, up to 20 individuals measured for SL and $\mathrm{M}_{\mathrm{W}}$ were randomly subsampled per month/site and individually stored at $-20^{\circ} \mathrm{C}$. Thereafter, the soles were thawed and entirely dissected under a binocular microscope to check for digenean metacercariae parasites (essentially located in muscle tissue), which were identified to the lowest taxa and counted (see Durieux et al., 2007a for details).

\subsection{Data analysis}

Sole density was calculated as: $\mathrm{D}=\mathrm{N}^{*} 1000 / \mathrm{S}$; with $\mathrm{D}$ as density (nb ind $1000 \mathrm{~m}^{-2}$ ), $\mathrm{N}$ as number of 0 -group sole captured per haul and $\mathrm{S}$ the sampled surface (in $\mathrm{m}^{2}$ ). Fulton condition factor was calculated as $\mathrm{K}=\left(\mathrm{M}_{\mathrm{W}} \times 100\right) / \mathrm{SL}^{3}$, with $\mathrm{M}_{\mathrm{W}}$ in $\mathrm{g}$ and $\mathrm{SL}$ in $\mathrm{cm}$. Levels of parasitic infection were assessed using classic epidemiological parameters: prevalence, the percentage of infected fish in fish sample; mean intensity, the mean number of parasites per infected fish; and mean abundance $(\mathrm{Ab})$, the mean number of parasites per fish (Bush et al., 1997).

Parasite taxa abundances were compared between months and sites using two-way ANOVAs followed by Tukey posthoc test. SL and K were respectively compared between months and sites using two-way ANOVAs followed by Tukey post hoc test. Discriminant Function Analysis (DFA) was performed for each month/strait in order to 
reclassify individuals to the different sampling sites using intensity (number of parasites in an individual fish) of the parasite taxa as explanatory variables. As part of the DFA, digenean metacercariae communities were compared by MANOVAs between sites for each month/strait using Pillai's trace test. Prior to the final set of DFAs, a first set of DFAs was performed with all sites together and showed high site fidelity of 0-group soles, thereafter since few connectivity seemed to occur between the two straits (Pertuis Breton and Pertuis d'Antioche), it was decided to perform DFAs on the two different straits separately for both ecological relevance and power of the analysis. A jackknife re-sampling approach was used to reclassify individuals to the different sites using the established DFA functions. Parasite intensities were $\log (n+1)$ transformed to meet normality and homogeneity of variance. Results were considered significant at $\alpha=5 \%$.

\section{Results}

\subsection{Spatio-temporal change in 0-group sole density}

A total of 1732 0-group soles were captured. From May onwards individuals were present on all sampled sites with peak densities in most sites located in shallow areas (Fig. 2). Densities varied strongly among sites: in the Pertuis Breton strait, PB4 had the highest density (189 ind $1000 \mathrm{~m}^{-2}$ ) compared to other sites (ranging from 2 to 15 ind $1000 \mathrm{~m}^{-2}$ ); in the Pertuis d'Antioche strait, densities were highest in PA1 and PA2 (70 and 61 ind $1000 \mathrm{~m}^{-2}$, respectively) compared to PA3 (7 ind $\left.1000 \mathrm{~m}^{-2}\right)$. From May to June, a sharp decline in 0-group sole density was observed in sites PB1, PB4, PA1 and PA2 whereas densities increased steadily in stations PB3 and PA3. From June to October densities remained relatively low in PB1 and PB2 $\left(<5\right.$ ind $\left.1000 \mathrm{~m}^{-2}\right)$; they were very high and increased in PB3 (from 62 to 106 ind $1000 \mathrm{~m}^{-2}$ ), whereas they dropped steadily in PB4 (from 77 to 1 ind $1000 \mathrm{~m}^{-2}$ ); densities were comparable between sites in the 
Pertuis d'Antioche strait (ranging between 7 and 20 ind $1000 \mathrm{~m}^{-2}$ ) and varied simultaneously for PA1 and PA2 with minima in August (around 1 ind $1000 \mathrm{~m}^{-2}$ ). For the two deeper sites (PB5 and PA4), we noted the lowest densities (less than 1 ind $1000 \mathrm{~m}^{-2}$ ) from April to August compared to shallow sites; however a clear increase was detected between August and October for both sites (4 and 7 ind $1000 \mathrm{~m}^{-2}$ in October respectively). Over the study period 0-group sole densities were clearly higher on shallow muddy sites (PB3, PB4, PA1, PA2 and PA3) than on shallow sandy sites (PB1 and PB2) and deeper sites (PB5 and PA4) (Fig. 1 and 2).

\subsection{Spatio-temporal change in digenean metacercariae infection of 0-group sole} 0-group soles $(\mathrm{n}=498)$ were infected by four species of digenean metacercariae: Timoniella spp. (Acanthostomatidae), Prosorhynchus crucibulum and Prosorhynchus sp. A (Bucephalidae), and Podocotyle sp. (Opecoelidae), with infection levels displaying significant spatio-temporal variations (Fig. 3; Table 1, 2, and 3). Over the study period (Fig. 3; Table 2): P. crucibulum was most abundant in mussel culture areas (i.e. PB1, PB2, PA2 and PA3; see Fig. 1) (Tukey post hoc test, $\mathrm{P}<0.05$ for all tests); Prosorhynchus sp. A was predominant in PB4, PA1 and PA2; Timoniella spp. was most abundant in PB3 (Tukey post hoc test, $\mathrm{P}<0.05$ for all tests); Podocotyle sp. predominant on PA1 (PB5 had higher mean abundance but much lower prevalence) (Tukey post hoc test, $\mathrm{P}<0.05$ for all tests). From May to June (Fig. 3; Table 2; Tukey post hoc test, $\mathrm{P}<0.05$ for all tests): Prosorhynchus crucibulum abundance increased significantly in PB1, PA2 and PA3; Prosorhynchus sp. A abundance increased significantly in PB1, PB4, and PA2; Timoniella spp. abundance increased significantly in PA3. From June to August (Fig. 3; Table 2; Tukey post hoc test, $\mathrm{P}<0.05$ for all tests): Prosorhynchus crucibulum abundance increased significantly in PB1 and PA3; 
Prosorhynchus sp. A abundance increased significantly in PB4, PA1, PA2 and PA3,

Timoniella spp. abundance increased significantly PB3. Finally, from August to October

(Fig. 3; Table 2; Tukey post hoc test, $\mathrm{P}<0.05$ for all tests), Prosorhynchus $\mathrm{sp.}$ A abundance increased significantly in PB4; Timoniella spp. abundance increased significantly in PA2.

\subsection{Discriminant Function Analysis results}

DFA revealed that digenean metacercariae communities of 0-group sole were significantly different between sites for each sampling month/strait (Table 3). DFAs allowed then reclassifying individuals to their different sites of origin based on their parasite community (Fig. 4; Table 4). Low levels of infection of the different parasites taxa in May did not allow to correctly reclassify most of individuals except for PB3 and PB4. However, from June onwards, correct reclassification rates reached very high values revealing the strong site-fidelity / sedentarity of 0-group sole in the different habitats sampled in the study. Highest correct reclassification rates were observed in August. In October, correct classification rate remained high overall but deeper sites (PB5 and PA4) showed poor reclassification rates. Cross-misclassification was observed between PB1 and PB2 due to their similar parasite community; misclassification occurred also in PA1 in August due to the very small sample size collected on this site at that time.

\subsection{Spatio-temporal change in standard length and condition factor of 0-group sole}

0-group sole increased in SL over the study period (Fig. 5). No difference was detected between sites in April, whereas significant differences were detected from May to October. In May, 0-group sole were significantly smaller in SL in PB1 than PB4, PA1, 
PA2 and PA3. In June, 0-group sole were larger in PB3 and PB4 compared to PB1 and all sites from the Pertuis d'Antioche strait. In August and October, 0-group sole were significantly larger in PB3 compared to all other sites (Fig. 5; Table 5).

Mean Fulton's condition factor K ranged 0.76 to above 1.2 and varied significantly between sites from May to October (Fig. 5; Table 5), however no consistent trend for the different sites over time could be distinguished.

\section{Discussion}

\subsection{Spatio-temporal change in 0-group density}

0-group sole densities peaked in May in shallow areas as a result of the colonisation process at this time in the Bay of Biscay (Dorel et al., 1991; Amara et al., 2000). 0group sole concentrate in shallow areas $(<5 \mathrm{~m}$ depth) on soft bottom with a clear preference for muddy substrates, which is consistent with previous knowledge on this species at this life stage (Rogers, 1992; Jager et al., 1993; Le Pape et al., 2003b; Vinagre et al., 2006). We noted that this peak in density occurred in June on sites sampled at the mouth of the rivers (i.e. PB3 and PA3). One of the main factors controlling 0-group sole colonisation in estuaries is the salinity gradient (Champalbert et al., 1994; Amara et al., 2000). Thus, even in this embayed areas with relatively low freshwater inputs, it is likely that 0 -group sole accumulated even further upstream of these rivers' mouth in May and then dispersed later on. A strong decline in 0-group sole densities was observed between May and June in most of the shallow sites (but PB3 and PA3). In plaice Pleuronectes platessa, this sharp drop in abundance generally corresponds to density dependent mortality and heavy predation processes (Nash and Geffen, 2000; Wennhage, 2002). However this is usually not the case for Solea solea and this decline 
in 0-group sole density after colonisation rather corresponds to the dispersal of the individuals over the available habitat (Dorel et al., 1991; Amara et al., 2000; van der Veer et al., 2001). In site PB4, although displaying highest densities in May, densities kept on declining to very low level reached in October. This could be related to predation, but this assumption appears unlikely since the distribution of the potential predators (mainly piscivorous fishes) is considered relatively homogeneous within the study area. Alternatively and more probably this might indicate that individuals have progressively left this area, which is notably more exposed to waves than the other sites. In October, densities increased slightly in the deeper areas (for both straits), which indicate the onset of the known migration of 0-group sole to deeper zone prior to winter in order to avoid very low temperatures that can occur in shallow areas during this period (Dorel et al., 1991; van der Veer et al., 2001). We noted also high spatial variability in densities, with for instance very high values in the Aiguillon Bay (PB3) from June through October, indicating potentially higher habitat suitability and quality. However, although these density data do provide information on colonisation, general distribution and bathymetric migration, they do not allow more precise inference about any movements of the individuals between the different parts of the shallow areas.

\subsection{Spatio-temporal change in digenean metacercariae infection of 0-group sole}

Over the study period, 0-group sole accumulated four taxa of digenean metacercariae (Prosorhynchus crucibulum, Prosorhynchus sp. A, Timoniella spp. and Podocotyle sp.), which is consistent with previous reports on this area (Durieux et al., 2007a; Durieux et al., 2007b). Parasite communities found in 0-group sole displayed intra-site variability; this is a classical observation that is explained by differential host susceptibility to a specific parasite (size, behaviour, immune defence, etc) (Combes, 2001). More 
surprisingly digenean metacercariae communities showed also a strong inter-site variability. Spatial heterogeneity in digenean parasite communities of intermediate host has already been described in various host-parasite systems with the presence/abundance of the upstream host being the primary determinant of infection levels in the downstream host (Smith, 2001; Thieltges and Reise, 2007). However, few studies had focused on spatial patterns infection in fish intermediate hosts at small spatial scale and those were performed mainly in freshwater environments (Balling and Pfeiffer, 1997; Marcogliese et al., 2001). The present study shows that, even within a highly dispersive macrotidal marine coastal environment, infection in fish second intermediate host is tightly linked to the heterogeneous distribution of the molluscs first intermediate hosts. In the digenean life cycle, although second intermediate host spectrum can be relatively large, the molluscan first intermediate host is generally very specific so that often only one or few closely phylogenetically related mollusc species can play this role for a given species (Cribb, 2005). Our results showed that each parasite taxa was clearly predominant in the close vicinity of their known respective molluscs taxa first intermediate hosts: Prosorhynchus crucibulum (Matthews, 1973) had highest infection levels in mussel (Mytilus spp.) culture areas; highest infection levels for Timoniella spp. (Maillard, 1974) were observed at the Aiguillon Bay site (PB3) where the mudsnail Hydrobia spp. are found abundantly on the surrounding mudflats; Podocotyle sp. (Koie, 1981) was predominant in site PA1 which was bordered by two rocky beds where the periwinkle Littorina sp. occurs; finally, despite the fact that the first intermediate host of Prosorhynchus sp. A remains unknown its spatial distribution revealed that mussels (Mytilus spp.) probably do not act as its first intermediate host.

\subsection{Use of digenean metacercariae as natural tags}


Since 0 -group sole locally acquired digenean metacercariae, these parasites could be used as natural tags according to MacKenzie's (2005) requirements. In the present study, factorial discriminant analysis results showed high levels of correct reclassification from after colonisation to autumn in the different sampled areas. These high correct reclassification rates (over 70\%) are comparable to those obtained by other studies at much larger spatial scale (hundreds of kilometres) using parasites to distinguish exploited marine fish stocks (Blaylock et al., 2003; Moore et al., 2003). We notice that our results are even higher than those obtained for the same species (Solea solea) along the Portuguese coast where only $45 \%$ of adult individuals were correctly reclassified between three regions (Marques et al., 2006). In May, poor reclassification rates allowed to discriminate only individuals from the Aiguillon Bay since Timoniella spp. was the only taxa showing significant levels of infection at this early period. In addition, as we have already seen, changing densities from May to June are likely to have indicated dispersal of individuals during this post-colonisation phase. From June onwards, however, fish from sites distant by only few kilometers could be accurately distinguished based on their digenean metacercariae communities only. Therefore the use of these parasites clearly allowed determining the high site fidelity of 0-group sole in the embayed system of the Pertuis Charentais. These findings are especially consistent with other field studies performed on 0-group sole in estuarine systems using conventional tags in the Tamar estuary by Coggan and Dando (1988) and more recently by Vinagre et al. (2008a) using a stable isotopes approach in the Tagus estuary. A large majority of individuals appears thus mainly sedentary in shallow coastal areas during their first growth period. Not only due to intra-site differential susceptibility of individuals in infection levels, reclassification of some individuals in other sites might indicate that a small proportion of migrants also exist in the population which could be 
observed in some case only from density data (see first section of the discussion).

Finally, we deduced that the high intra-site variability in digenean metacercariae communities observed in deeper sites in October, reflected the arrival of differentially infected fish from a more upstream and / or shallow part of the nursery as a result of the migration towards deeper waters prior to winter. To date, this is the first time that digenean metacercariae are successfully used make inference about fish juvenile habitat use at such a small spatial scale in nearshore coastal areas.

\subsection{Spatial patterns in habitat quality}

0-group sole displayed a spatio-temporal variability in Fulton's condition index, but no clear spatial pattern could be distinguished over the study period. In fact, water content and fullness of digestive tracts of fish induce high variability of this morphometric condition index and it has often been shown as a relatively poorly sensitive proxy of habitat quality (Gilliers et al., 2006; Amara et al., 2007). Since 0-group sole displayed strong site fidelity in different parts of the habitat, the evolution of the size can be considered as the reflect of growth performances of individuals on the different sites (Le Pape et al., 2003a), and appears as a relevant metrics of fish habitat quality (Gilliers et al., 2006; Vinagre et al., 2008b). Our results showed significant differences in standard length of 0-group sole between the different sites over the study period with fish caught in the Aiguillon Bay (PB3) exhibiting clearly larger size. Such small scale spatial variation in growth / habitat quality has already been reported in various geographic locations for flatfish using different approaches such as otolith daily increment (Vinagre et al., 2008b), RNA/DNA ratio (Malloy et al., 1996; Yamashita et al., 2003; Vinagre et al., 2008b), growth performances in cage experiments (Able et al., 1999; Necaise et al., 2005) or comparison of realised growth to potential growth (Hurst and Abookire, 2006). 
Various factors interacting together can influence habitat quality for flatfish juveniles such as habitat structure, water temperature and oxygen level, prey availability, pollution, etc (Gibson, 1994; Beck et al., 2001; Vasconcelos et al., 2007). Parasitism is often overlooked as a potential factor influencing fish habitat quality although it has been reported several times that parasites and especially digenean metacercariae can dramatically alter fish performances (Lemly and Esch, 1984; Collyer and Stockwell, 2004). In the present case, however, parallel investigations on the effects of metacercariae on 0 -group sole showed that their pathogenicity was relatively low (Durieux, 2007) so that they can only be considered as an additional stressor. At the scale of the Bay of Biscay, Le Pape et al. (2007) have shown that after physical factors and notably bathymetry and sediment structure, prey quantity and quality are determinant factors driving habitat suitability and quality for 0-group sole. Within the Pertuis Charentais area, the Aiguillon Bay is a highly productive system based on microphytobenthic primary production supporting a large compartment of benthic macrofauna (Degré et al., 2006). Although a complete set of environmental variables was not available, known determinant physical factors did not display variation that would have explain the observed difference in sizes and densities, however we assume that better food quantity and/or quality in the Aiguillon Bay might play an important role in its observed higher habitat quality for 0-group sole.

In the literature, "juvenile habitat" and "nursery habitat" are often incorrectly confounded (Dahlgren et al., 2006). However nursery habitat is by definition a part of the juvenile habitat where abundance and/or growth and/or survival and/or movements to the adult population are higher per unit area (Beck et al., 2001). Compared to the total 
estimated sustainable habitat for 0-group sole in the Pertuis Breton (Le Pape et al., 2003b), only a small proportion of this habitat appears to be of high quality and can really be qualified stricto sensu as nursery habitat according to Beck et al. (2001). Movements of fish between the different parts of the habitat would have the effect of dampening the heterogeneity of habitat quality. However individuals displayed strong site-fidelity even in sub-optimal areas as often reported for flatfish juveniles (Malloy and Targett, 1991; Yamashita et al., 2003; Vinagre et al., 2008b). Strong site-fidelity and limited movements of flatfish juveniles (herein exemplified) constitutes an evolutionary trait that allows them to decrease energy expenditure and reduces encounters with predators (Gibson, 1997). They are alternatively extremely dependent and vulnerable to local conditions, which make them very good indicators of the quality of their habitat.

\subsection{Conclusions}

This study reports new information on the dynamics of the host-parasite system, 0 group sole - digenean metacercariae. 0-group sole concentrated in shallow and muddy areas of the Pertuis Charentais. 0-group sole accumulated digenean metacercariae with a clear spatial pattern where communities were essentially determined by the distribution of the mollusc first intermediate host. Digenean metacercariae allowed determination of the high site-fidelity of 0-group sole with a large majority of individuals being sedentary in the different part of the habitat during their first period of growth. Moreover, size and densities revealed spatial heterogeneity in habitat quality. The Aiguillon Bay could thus be identified as sensu stricto nursery habitat for 0-group sole within the Pertuis Breton area. Hereby the use of digenean metacercariae as natural tags appears as a novel powerful tool to evaluate habitat use and movements of juvenile flatfish in coastal areas 
at relatively small spatial scale, which could find applications in conservation and coastal zone management programs.

\section{Acknowledgements}

We are very grateful to J. Grizon and numerous volunteers for valuable help with field sampling. Research project was funded by IFREMER and the Conseil Régional de Poitou-Charentes. 
1

2

3

4

5

6

\section{References}

Able, K.W., Manderson, J.P., Studholme, A.L., 1999. Habitat quality for shallow water fishes in urban estuary: the effect of man-made structures on growth. Mar. Ecol. Prog. Ser. 187, 227-235.

Amara, R., Lagardère, F., Désaunay, Y., Marchand, J., 2000. Metamorphosis and estuarine colonisation in the common sole, Solea solea (L.): implications for recruitment regulation. Oceanol. Acta 23, 469-484.

Amara, R., Meziane, T., Gilliers, C., Hermel, G., Laffargue, P., 2007. Growth and condition indices in juvenile sole Solea solea measured to assess the quality of essential fish habitat. Mar. Ecol. Prog. Ser. 351, 201-208.

Balling, T.E., Pfeiffer, W., 1997. Location-dependent infection of fish parasites in Lake Constance. J. Fish Biol. 51, 1025-1032.

Beck, M.W., Heck, K.L., Able, K.W., Childers, D.L., Eggleston, D.B., Gillanders, B.M., Halpern, B., Hays, C.G., Hoshino, K., Minello, T.J., Orth, R.J., Sheridan, P.F., Weinstein, M.P., 2001. The identification, conservation, and management of estuarine and marine nurseries for fish and invertebrates. Bioscience 51, 633641.

Blaylock, R.B., Margolis, L., Holmes, J.C., 2003. The use of parasites in discriminating stocks of Pacific halibut (Hippoglossus stenolepis) in the northeast Pacific. Fishery Bulletin 101, 1-9.

Bush, A.O., Lafferty, K.D., Lotz, J.M., Shostak, A.W., 1997. Parasitology meets ecology on its own terms: Margolis et al. revisited. J. Parasitol. 83, 575-583.

Champalbert, G., Marchand, J., Le Campion, J., 1994. Rheotaxis in juvenile sole Solea solea (L.): influence of salinity and light conditions. Neth. J. Sea Res. 32, 309319. 
Coggan, R.A., Dando, P.R., 1988. Movements of juvenile Dover sole, Solea solea (L.), in the Tamar estuary, south western England. J. Fish Biol. 33, 177-184.

Collyer, M.L., Stockwell, C.A., 2004. Experimental evidence for costs of parasitism for a threatened species, White Sands pupfish (Cyprinodon tularosa). J. Anim. Ecol. $73,821-830$.

Combes, C., 2001. Parasitism. The ecology and evolution of intimate interactions. Chicago University Press, Chicago, 728 pp.

Cribb, T.H., 2005. Digenea (endoparasitic flukes). In: Rhode, K. (Ed.), Marine Parasitology. CSIRO Publishing, Melbourne.

Dahlgren, C.P., Kellison, G.T., Adams, A.J., Gillanders, B.M., Kendall, M.S., Layman, C.A., Ley, J.A., Nagelkerken, I., Serafy, J.E., 2006. Marine nurseries and effective juvenile habitats: concepts and applications. Mar. Ecol. Prog. Ser. 312, 291-295.

Degré, D., Leguerrier, D., Armynot du Chatelet, E., Rzeznik, J., Auguet, J.-C., Dupuy, C., Marquis, E., Fichet, D., Struski, C., Joyeux, E., Sauriau, P.-G., Niquil, N., 2006. Comparative analysis of the food webs of two intertidal mudflats during two seasons using inverse modelling: Aiguillon Cove and Brouage Mudflat, France. Estuar. Coast. Shelf Sci. 69, 107-124.

Dorel, D., Koutsikopoulos, C., Désaunay, Y., Marchand, J., 1991. Seasonal distribution of young sole (Solea solea (L.)) in the nursery ground of the Bay of Vilaine (Northern Bay of Biscay). Neth. J. Sea Res. 27, 297-306.

Durieux, E., 2007. Ecology of the host - parasite system, 0-group sole (Solea solea) digenean metacercariae: dynamics and effects of the infection. University of La Rochelle, pp. 187. 
Durieux, E.D.H., Bégout, M.-L., Sasal, P., 2007a. Spatial variability in digenean metacercariae infection of 0-group common sole, Solea solea, among different nurseries along the French Atlantic coast. Dis. Aquat. Org. 75, 221-228.

Durieux, E.D.H., Galois, R., Bégout, M.-L., Sasal, P., Lagardère, F., 2007b. Temporal changes in lipid condition and parasitic infection by digenean metacercariae of young-of-year common sole Solea solea (L.) in an Atlantic nursery ground (Bay of Biscay, France). J. Sea Res. 57, 162-170.

Eastwood, P.D., Meaden, G.J., Carpentier, A., Rogers, S.I., 2003. Estimating limits to the spatial extent and suitability of sole (Solea solea) nursery grounds in the Dover Strait. J. Sea Res. 50, 151-165.

El-Darsh, H.E.M., Whitfield, P.J., 1999. The parasite community infecting flounders, Platichthys flesus, in the tidal Thames. Journal of Helminthology 73, 203-214.

Gibson, R.N., 1994. Impact of habitat quality and quantity on the recruitment of juvenile flatfishes. Neth. J. Sea Res. 32, 191-206.

Gibson, R.N., 1997. Behaviour and the distribution of flatfishes. J. Sea Res. 37, 241256.

Gillanders, B.M., Able, K.W., Brown, J.A., Eggleston, D.B., Sheridan, P.F., 2003. Evidence of connectivity between juvenile and adult habitats for mobile marine fauna: an important component of nurseries. Mar. Ecol. Prog. Ser. 247, 281-295.

Gilliers, C., Le Pape, O., Desaunay, Y., Morin, J., Guerault, D., Amara, R., 2006. Are growth and density quantitative indicators of essential fish habitat quality? An application to the common sole Solea solea nursery grounds. Estuar. Coast. Shelf Sci. 69, 96-106.

Goulletquer, P., Le Moine, O., 2002. Shellfish farming and coastal zone management (CZM) development in the Marennes-Oléron Bay and Charentais Sounds 
(Charente Maritime, France): a review of recent development. Aquac. Int. 10, 507-525.

Hurst, T.P., Abookire, A.A., 2006. Temporal and spatial variation in potential and realized growth rates of age-0 year northern rock sole. J. Fish Biol. 68, 905-919.

ICES, 2005. Report of the ICES Advisory Committee on Fishery Management, Advisory Committee on the Marine Environment and Advisory Committee on Ecosystems, 2005. Volumes 1 - 11. 1, ICES Advice. ICES, pp. 418 pp.

Jager, Z., Kleef, H.L., Tydeman, P., 1993. The distribution of 0-group flatfish in relation to abiotic factors on the tidal flats in the brackish Dollard (Ems Estuary, Wadden Sea). J. Fish Biol. 43, 31-43.

Koie, M., 1981. On the morphology and life-history of Podocotyle reflexa (Creplin, 1825) Odhner, 1905, and a comparison of its developmental stages with those of P. atomon (Rudolphi, 1802) Odhner, 1905 (Trematoda, Opecoelidae). Ophelia 20, 17-43.

Le Pape, O., Holley, J., Guérault, D., Désaunay, Y., 2003a. Quality of coastal and estuarine essential fish habitats: estimations based on the size of juvenile common sole (Solea solea L.). Estuar. Coast. Shelf Sci. 58, 793-803.

Le Pape, O., Chauvet, F., Mahevas, S., Lazure, P., Guérault, D., Désaunay, Y., 2003b. Quantitative description of habitat suitability for the juvenile common sole (Solea solea, L.) in the Bay of Biscay (France) and the contribution of different habitats to the adult population. J. Sea Res. 50, 139-149.

Le Pape, O., Baulier, L., Cloarec, A., Martin, J., Le Loc'h, F., Desaunay, Y., 2007. Habitat suitability for juvenile common sole (Solea solea, L.) in the Bay of Biscay (France): A quantitative description using indicators based on epibenthic fauna. J. Sea Res. 57, 126-136. 
Lemly, A.D., Esch, G., 1984. Population Biology of the Trematode Uvulifer ambloplitis (Hughes, 1927) in Juvenile Bluegill Sunfish, Lepomis macrochirus, and Largemouth Bass, Micropterus salmoides J. Parasitol. 70, 466-474.

MacKenzie, K., 2005. Parasites as biological tags. In: Rhode, K. (Ed.), Marine parasitology. CABI Publishing, Oxon, pp. 351-355.

Maillard, C., 1974. Cycle évolutif de Timoniella praeteritum (Loss 1901) (Trematoda, Acanthostomidae) parasite de Morone labrax (teleostei, Serranidae). Bull. Soc. Zool. Fr. 99, 245-257.

Malloy, K.D., Targett, T.E., 1991. Feeding, growth and survival of juvenile summer flounder Paralichtys dentatus: experimental analysis of the effects of temperature and salinity. Mar. Ecol. Prog. Ser. 72, 213-223.

Malloy, K.D., Yamashita, Y., Yamada, H., Targett, T.E., 1996. Spatial and temporal patterns of juvenile stone flounder Kareius bicoloratus growth rates during and after settlement. Mar. Ecol. Prog. Ser. 131, 49-59.

Marcogliese, D.J., Dumont, P., Gendron, A.D., Mailhot, Y., Bergeron, E., McLaughlin, J.D., 2001. Spatial and temporal variation in abundance of Diplostomum spp. in walleye (Stizostedion vitreum) and white suckers (Catostomus commersoni) from the St. Lawrence River. Canadian Journal of Zoology 79, 355-369.

Marques, J.F., Teixeira, C.M., Cabral, H.N., 2006. Differentiation of economically important flatfish populations along the Portuguese coast: evidence from morphology and parasitology. Fish. Res. 81, 293-305.

Matthews, R.A., 1973. The life-cycle of Prosorhynchus crucibulum (Rudolphi, 1819 Odhner, 1905, and a comparison of its cercaria with that of Prosorhynchus squamatus Odhner, 1905. Parasitology 66, 133-164. 
Moore, B.R., Buckworth, R.C., Moss, H., Lester, R.J.G., 2003. Stock dicrimination and movements of narrow-barred Spanish mackerel across northern Australia as indicated by parasites. J. Fish Biol. 63, 765-779.

Nash, R.D.M., Geffen, A.J., 2000. The influence of nursery ground processes in the determination of year-class strength in juvenile plaice Pleuronectes platessa L. in Port Erin Bay, Irish Sea. J. Sea Res. 44, 101-110.

Necaise, A.M.D., Ross, S.W., Miller, J.M., 2005. Estuarine habitat evaluation measured by growth of juvenile summer flounder Paralichthys dentatus in a North Carolina estuary. Mar. Ecol. Prog. Ser. 285, 157-168.

Olson, R.E., Pratt, I., 1973. Parasites as Indicators of English Sole (Parophrys vetulus) Nursery Grounds. Trans Am Fish Soc 102, 405-411.

Rice, J.C., 2005. Understanding fish habitat ecology to achieve conservation. J. Fish Biol. 67, 1-22.

Rogers, S.I., 1992. Environmental factors affecting the distribution of sole (Solea solea (L.)) within a nursery area. Neth. J. Sea Res. 29, 153-161.

Smith, N.F., 2001. Spatial heterogeneity in recruitment of larval trematodes to snail intermediate hosts. Oecologia 127, 115-122.

Sujatha, K., Madhavi, R., 1990. Comparison of digenean faunas of sillaginid fishes from inshore and offshore waters of Visakhapatnam Coast, Bay of Bengal. J. Fish Biol. 36, 693-699.

Thieltges, D.W., Reise, K., 2007. Spatial heterogeneity in parasite infections at different spatial scales in an intertidal bivalve. Oecologia 150, 569-581.

van der Veer, H.W., Dapper, R., Witte, J.I.J., 2001. The nursery function of the intertidal areas in the western Wadden Sea for 0-group sole Solea solea (L.). J. Sea Res. 45, 271-279. 
Vasconcelos, R.P., Reis-Santos, P., Fonseca, V., Maia, A., Ruano, M., França, S., Vinagre, C., Costa, M.J., Cabral, H., 2007. Assessing anthropogenic pressures on estuarine fish nurseries along the Portuguese coast: A multi-metric index and conceptual approach. Sci. Tot. Env. 374, 199-215.

Vignon, M., Morat, F., Galzin, R., Sasal, P., 2008. Evidence for spatial limitation of the bluestripe snapper Lutjanus kasmira in French Polynesia from parasite and otolith shape. J. Fish Biol. 73, 2305-2320.

Vinagre, C., Fonseca, V., Cabral, H., Costa, M.J., 2006. Habitat suitability index models for the juvenile soles, Solea solea and Solea senegalensis, in the Tagus estuary: Defining variables for species management. Fish. Res. 82, 140-149.

Vinagre, C., Salgado, J., Costa, M.J., Cabral, H.N., 2008a. Nursery fidelity, food web interactions and primary sources of nutrition of the juveniles of Solea solea and S. senegalensis in the Tagus estuary (Portugal): A stable isotope approach. Estuar. Coast. Shelf Sci. 76, 255-264.

Vinagre, C., Fonseca, V., Maia, A., Amara, R., Cabral, H., 2008b. Habitat specific growth rates and condition indices for the sympatric soles Solea solea (Linnaeus, 1758) and Solea senegalensis (Kaup 1858), in the Tagus estuary, Portugal, based on otolith daily increments and RNA-DNA ratio. J. Appl. Ichthyo. 24, 163-169.

Wennhage, H., 2002. Vulnerability of newly settled plaice (Pleuronectes platessa L.) to predation: effects of habitat structure and predator functional response. J. Exp. Mar. Biol. Ecol. 269, 129-145.

Yamashita, Y., Tominaga, O., Takami, H., Yamada, H., 2003. Comparison of growth, feeding and cortisol level in Platichthys bicoloratus juveniles between estuarine and nearshore nursery grounds. J. Fish Biol. 63, 617-630. 
Table 1: Parasitological parameters (prevalence and mean intensity) for the four taxa of digenean metacercariae infecting 0-group sole Solea solea collected from April to October 2005 in the Pertuis Charentais area, Bay of Biscay, France (no parasites were found in April).

\begin{tabular}{|c|c|c|c|c|c|c|c|c|c|c|c|}
\hline \multirow{2}{*}{\multicolumn{2}{|c|}{ Parasite taxa }} & \multirow[t]{2}{*}{ Month } & \multicolumn{9}{|c|}{ Sites } \\
\hline & & & PB 1 & PB 2 & PB 3 & PB 4 & PB 5 & PA 1 & PA 2 & PA 3 & PA 4 \\
\hline \multirow{16}{*}{$\begin{array}{l}0 \\
\frac{0}{0} \\
\frac{\pi}{\pi} \\
0 \\
0\end{array}$} & \multirow{4}{*}{ Prosorhynchus crucibulum } & May & 5.0 & - & - & - & - & - & - & - & - \\
\hline & & June & 81.8 & 100.0 & 15.0 & 45.0 & & 20.0 & 100.0 & 80.0 & 33.3 \\
\hline & & August & 100.0 & 100.0 & 65.0 & 60.0 & & 100.0 & 84.6 & 95.0 & \\
\hline & & October & 100.0 & 100.0 & 65.0 & 62.5 & 100.0 & 75.0 & 100.0 & 95.0 & 9.1 \\
\hline & \multirow{4}{*}{ Prosorhynchus sp. A } & May & - & 20.0 & - & 10.0 & - & - & - & - & - \\
\hline & & June & 90.9 & 50.0 & - & 75.0 & & 20.0 & 90.0 & 45.0 & 83.3 \\
\hline & & August & 42.1 & 40.0 & 5.0 & 95.0 & & 100.0 & 100.0 & 100.0 & \\
\hline & & October & 14.3 & 16.7 & 10.0 & 100.0 & 18.8 & 100.0 & 100.0 & 90.0 & 100.0 \\
\hline & \multirow{4}{*}{ Timoniella spp. } & May & 35 & 80.0 & 100.0 & 20.0 & - & 35.0 & 65.0 & 55.0 & - \\
\hline & & June & 72.7 & 100.0 & 100.0 & 50.0 & & 35.0 & 30.0 & 100.0 & 66.7 \\
\hline & & August & 63.2 & 80.0 & 100.0 & 50.0 & & 50.0 & 53.8 & 100.0 & \\
\hline & & October & 50 & 100.0 & 100.0 & 75.0 & 100.0 & 90.0 & 100.0 & 95.0 & 63.6 \\
\hline & \multirow{4}{*}{ Podocotyle sp. } & May & - & - & - & - & - & - & - & - & - \\
\hline & & June & - & - & - & - & & - & - & - & - \\
\hline & & August & 5.3 & - & - & - & & 50.0 & 7.7 & 10.0 & \\
\hline & & October & - & 33.3 & - & 25.0 & 30.8 & 90.0 & 25.0 & 25.0 & 36.4 \\
\hline \multirow{16}{*}{ 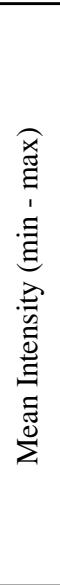 } & \multirow{4}{*}{ Prosorhynchus crucibulum } & May & $2.0(0-1)$ & - & - & - & - & - & - & - & - \\
\hline & & June & $10.0(1-18)$ & $3.5(0-11)$ & $1.3(0-2)$ & $3.6(0-11)$ & & $3.5(0-6)$ & $5.5(1-14)$ & $10.0(0-28)$ & $1.0(0-1)$ \\
\hline & & August & $34.1(5-88)$ & $24.6(1-47)$ & $3.9(0-13)$ & $3.7(0-13)$ & & $2.0(2-2)$ & $17.5(0-57)$ & $27.0(0-80)$ & \\
\hline & & October & $45.5(3-108)$ & $36.7(16-69)$ & $3.8(0-14)$ & $5.8(0-19)$ & $10.0(2-26)$ & $7.4(0-18)$ & $18.5(2-49)$ & $19.1(0-80)$ & $88.0(0-28)$ \\
\hline & \multirow{4}{*}{ Prosorhynchus sp. A } & May & - & $2.0(0-2)$ & - & $1.0(0-1)$ & - & - & - & - & - \\
\hline & & June & $3.8(0-13)$ & $2.5(0-4)$ & - & $3.9(0-10)$ & & $1.0(0-1)$ & $5.4(0-14)$ & $2.7(0-8)$ & $6.0(0-12)$ \\
\hline & & August & $7.1(0-44)$ & $1.5(0-2)$ & $42.0(0-42)$ & $13.1(0-33)$ & & $13.0(5-21)$ & $57.2(2-181)$ & $5.6(1-25)$ & \\
\hline & & October & $1.5(0-2)$ & $22.0(0-22)$ & $11.0(0-21)$ & $122.6(3-400)$ & $42.67(0-50)$ & $23.5(2-97)$ & $44.6(2-114)$ & $8.1(0-84)$ & $38.5(2-94)$ \\
\hline & \multirow{5}{*}{ Timoniella spp. } & May & $5.4(0-24)$ & $7.8(0-27)$ & $17.8(1-46)$ & $3.0(0-7)$ & - & $1.7(0-3)$ & $2.7(0-4)$ & $4.4(0-12)$ & - \\
\hline & & June & $3.8(0-8)$ & $15.3(6-23)$ & $58.8(19-93)$ & $10.6(0-36)$ & & $6.7(0-20)$ & $2.2(0-4)$ & $21.3(1-44)$ & $15.0(0-32)$ \\
\hline & & August & $25.3(0-73)$ & $10.3(0-20)$ & $301.8(61-666)$ & $4.2(0-9)$ & & $25.0(0-25)$ & $4.7(0-17)$ & $14.3(1-65)$ & \\
\hline & & October & $28.1(0-146)$ & $13.3(2-29)$ & $217.6(7-845)$ & $10.5(0-43)$ & $150.5(7-984)$ & $10.0(0-46)$ & $23.1(2-123)$ & $34.8(0-213)$ & $20.4(0-39)$ \\
\hline & & May & - & - & - & - & - & - & - & - & - \\
\hline & \multirow{3}{*}{ Podocotyle sp. } & June & - & - & - & - & & - & - & - & - \\
\hline & & August & $2.0(0-2)$ & - & - & - & & $14.0(0-14)$ & $1.0(0-1)$ & $0.5(0-1)$ & \\
\hline & & October & - & $1.5(0-2)$ & - & $1.0(0-1)$ & $183.3(0-728)$ & $6.4(0-37)$ & $4.2(0-14)$ & $5.8(0-21)$ & $1.3(0-2)$ \\
\hline
\end{tabular}


178 Table 2: summary of two-way ANOVAs testing differences between months and sites

179 in abundance of the different parasites taxa infecting 0-group sole Solea solea. Sole

180 were collected from April to October 2005 in the Pertuis Charentais area, Bay of

181 Biscay, France (no parasites were found in April).

\begin{tabular}{llrrr}
\hline Variable & Source & df & \multicolumn{1}{c}{ F } & P \\
\hline Prosorhynchus crucibulum & Month & 3 & 103.050 & $<0.001$ \\
& Site & 8 & 36.144 & $<0.001$ \\
& Month x Site & 21 & 6.326 & $<0.001$ \\
& Error & 438 & & \\
\hline Prosorhynchus sp. A & Month & 3 & 59.457 & $<0.001$ \\
& Site & 8 & 49.735 & $<0.001$ \\
& Month x Site & 21 & 15.238 & $<0.001$ \\
& Error & 438 & & \\
\hline Timoniella spp. & Month & 3 & 27.788 & $<0.001$ \\
& Site & 8 & 63.211 & $<0.001$ \\
& Month x Site & 21 & 4.743 & $<0.001$ \\
& Error & 438 & & \\
\hline Podocotyle sp. & Month & 1 & 0.694 & 0.434 \\
& Site & 7 & 4.743 & $<0.001$ \\
& Month x Site & 7 & 0.447 & 0.871 \\
& Error & 215 & & \\
\hline
\end{tabular}

182

183 
184 Table 3: summary of MANOVAs comparing digenean metacercariae infecting 0-group

185 sole Solea solea between sites sampled from April to October 2005 in the Pertuis

186 Charentais area, Bay of Biscay, France (no parasites were found in April). Analysis was

187 performed for each sampling month and strait (PB: Pertuis Breton; PA: Pertuis

188 d'Antioche).

\begin{tabular}{|c|c|c|c|c|c|}
\hline Month & Strait & Pillai's trace & $\mathrm{F}$ & df & $\mathrm{P}$ \\
\hline \multirow{2}{*}{ May } & PB & 0.75 & 5.81 & $9-156$ & $<0.0001$ \\
\hline & $\mathrm{PA}$ & 0.13 & 2.86 & $3-58$ & 0.045 \\
\hline \multirow{2}{*}{ June } & PB & 1.14 & 10.47 & $9-153$ & $<0.0001$ \\
\hline & PA & 1.43 & 18.79 & $9-186$ & $<0.0001$ \\
\hline \multirow{2}{*}{ August } & PB & 1.52 & 15.04 & $12-177$ & $<0.0001$ \\
\hline & PA & 1.05 & 8.33 & $8-60$ & $<0.0001$ \\
\hline \multirow{2}{*}{ October } & PB & 1.68 & 10.13 & $16-224$ & $<0.0001$ \\
\hline & PA & 1.07 & 9.09 & $12-198$ & $<0.0001$ \\
\hline
\end{tabular}

190 
191 Table 4: summary of Discriminant Function Analysis (DFA) showing reclassification of

192 0-group sole Solea solea individuals to the different sites based on abundances of each

193 of the four taxa of digenean metacercariae. DFAs were performed for each sampling

194 month and strait (PB: Pertuis Breton; PA: Pertuis d'Antioche). 0-group sole Solea solea

195 were collected from April to October 2005 in the Pertuis Charentais area, Bay of

196 Biscay, France (no parasites were found in April). Values in bold represent correct

197 assignments.

\begin{tabular}{|c|c|c|c|c|c|c|c|c|c|c|c|}
\hline \multirow[t]{2}{*}{ Month } & \multirow[t]{2}{*}{ Site } & \multicolumn{5}{|c|}{ Predicted site } & \multirow[t]{2}{*}{ Site } & \multicolumn{4}{|c|}{ Predicted site } \\
\hline & & PB1 & PB2 & PB3 & PB4 & PB5 & & PA1 & PA2 & PA3 & PA4 \\
\hline \multirow{6}{*}{ May } & PB 1 & 15 & - & 10 & 75 & & PA1 & 65 & 15 & 20 & - \\
\hline & PB2 & 40 & $\mathbf{0}$ & 20 & 40 & & PA2 & 35 & 10 & 55 & - \\
\hline & PB3 & 9 & - & 91 & - & & PA3 & 45 & 50 & 5 & - \\
\hline & PB4 & 10 & 10 & 5 & 75 & & PA4 & 100 & - & - & - \\
\hline & PB5 & & & & & & \multirow{2}{*}{\multicolumn{5}{|c|}{$26 \%$ of all individuals correctly classified to their site of origin }} \\
\hline & $50 \%$ of a & ividua & ectly o & ed to & te of 0 & & & & & & \\
\hline \multirow{6}{*}{ June } & PB1 & 73 & - & - & 27 & & PA1 & 80 & 5 & 10 & 5 \\
\hline & PB2 & 25 & 25 & 25 & 25 & & PA2 & 15 & 85 & - & - \\
\hline & PB3 & - & 5 & 95 & - & & PA3 & - & 10 & 90 & - \\
\hline & PB4 & 15 & 5 & 10 & 70 & & PA4 & 17 & 17 & 17 & 33 \\
\hline & PB5 & & & & & & \multirow{2}{*}{\multicolumn{5}{|c|}{$80 \%$ of all individuals correctly classified to their site of origin }} \\
\hline & $76 \%$ of a & ividua & ectly o & ed to & te of o & & & & & & \\
\hline \multirow{6}{*}{ August } & PB1 & 79 & 5 & 11 & 5 & & PA1 & $\mathbf{0}$ & 50 & 50 & \\
\hline & PB2 & 80 & - & & 20 & & PA2 & 8 & 77 & 15 & \\
\hline & PB3 & 5 & - & 95 & - & & PA3 & - & 15 & 85 & \\
\hline & PB4 & 10 & & - & 90 & & PA4 & & & & \\
\hline & PB5 & & & & & & $76 \%$ of a & jidual & ctly cl & d to th & of origin \\
\hline & $81 \%$ of a & ividua & ctly & ed to $t$ & te of 0 & & & & & & \\
\hline \multirow{5}{*}{ October } & PB1 & 79 & 14 & 7 & - & - & PA1 & 70 & 15 & 5 & 10 \\
\hline & PB2 & 100 & 0 & - & - & - & PA2 & 10 & 80 & 10 & - \\
\hline & PB3 & - & - & 85 & 5 & 10 & PA3 & 10 & - & 90 & - \\
\hline & PB4 & - & - & 13 & 88 & - & PA4 & 27 & 18 & 27 & 45 \\
\hline & PB5 & 8 & 8 & 31 & 8 & 46 & \multicolumn{5}{|c|}{$75 \%$ of all individuals correctly classified to their site of origin } \\
\hline
\end{tabular}


199 Table 5: summary of two-way ANOVAs testing differences between months and sites 200 in standard length (SL) and Fulton's condition factor (K), respectively, for 0-group sole 201 Solea solea collected from April to October 2005 in the Pertuis Charentais area, Bay of 202 Biscay, France.

\begin{tabular}{llrrr}
\hline Variable & Source & df & F & P \\
\hline SL & Month & 4 & 213.573 & $<0.001$ \\
& Site & 7 & 14.045 & $<0.001$ \\
& Month x Site & 23 & 7.256 & $<0.001$ \\
& Error & 1274 & & \\
\hline K & Month & 4 & 8.550 & $<0.001$ \\
& Site & 5 & 1.694 & 0.134 \\
& Month x Site & 25 & 4.420 & $<0.001$ \\
& Error & 611 & & \\
\hline
\end{tabular}

203 


\section{Figure captions}

206

207

Figure 1: Map of the Pertuis Charentais area (Bay of Biscay, France) with location of

the nine sites where 0-group sole Solea solea were sampled using a standard beam trawl from April to October 2005.

Figure 2: density of 0-group sole Solea solea in the different sites sampled from April to October 2005 in the Pertuis Charentais area, Bay of Biscay, France.

Figure 3: Mean abundance ( $\mathrm{Ab} \pm \mathrm{SE}$ ) of the four taxa of digenean metacercariae infecting

0-group sole Solea solea collected from April to October 2005 in the Pertuis Charentais area, Bay of Biscay, France (no parasites were found in April).

Figure 4: Scatterplot of scores along the first two axes derived from discriminant functions analysis (DFA) of parasites taxa variables measured for 0-group sole Solea solea individuals from different sites in the Pertuis Charentais area, Bay of Biscay, France. DFAs were performed for each sampling month and strait (PB: Pertuis Breton; PA: Pertuis d'Antioche).

Figure 5: Comparison between sites of mean standard length (SL $\pm S E)$ and Fulton's condition factor $(\mathrm{K} \pm \mathrm{SE})$ of 0-group sole Solea solea collected from April to October 2005 on the different sites of the Pertuis Charentais area, Bay of Biscay, France. Letters represent significant differences at $\alpha=5 \%$ (two-way ANOVAs followed by Tukey post hoc tests). 


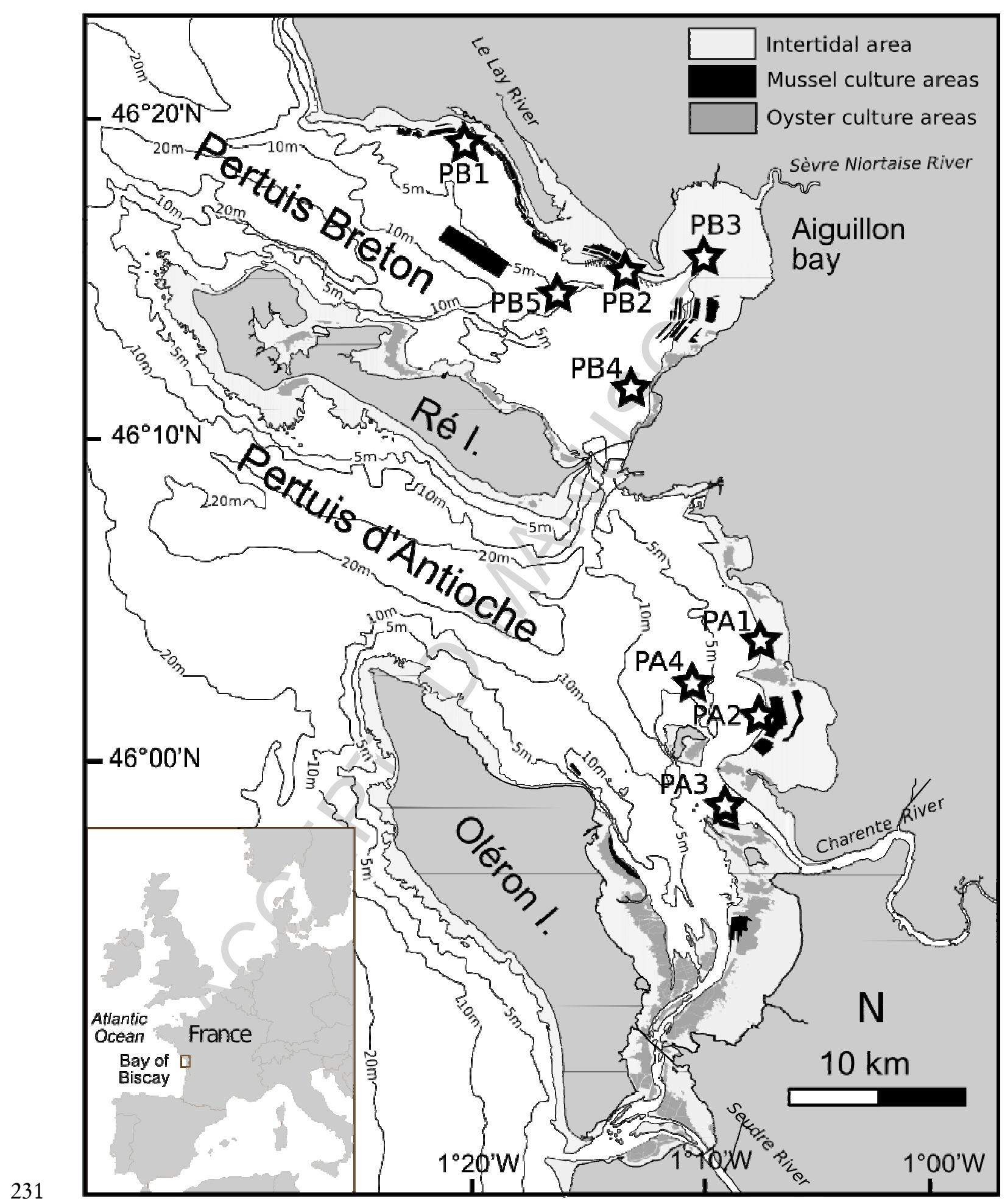

$232 \quad$ Fig 1. 


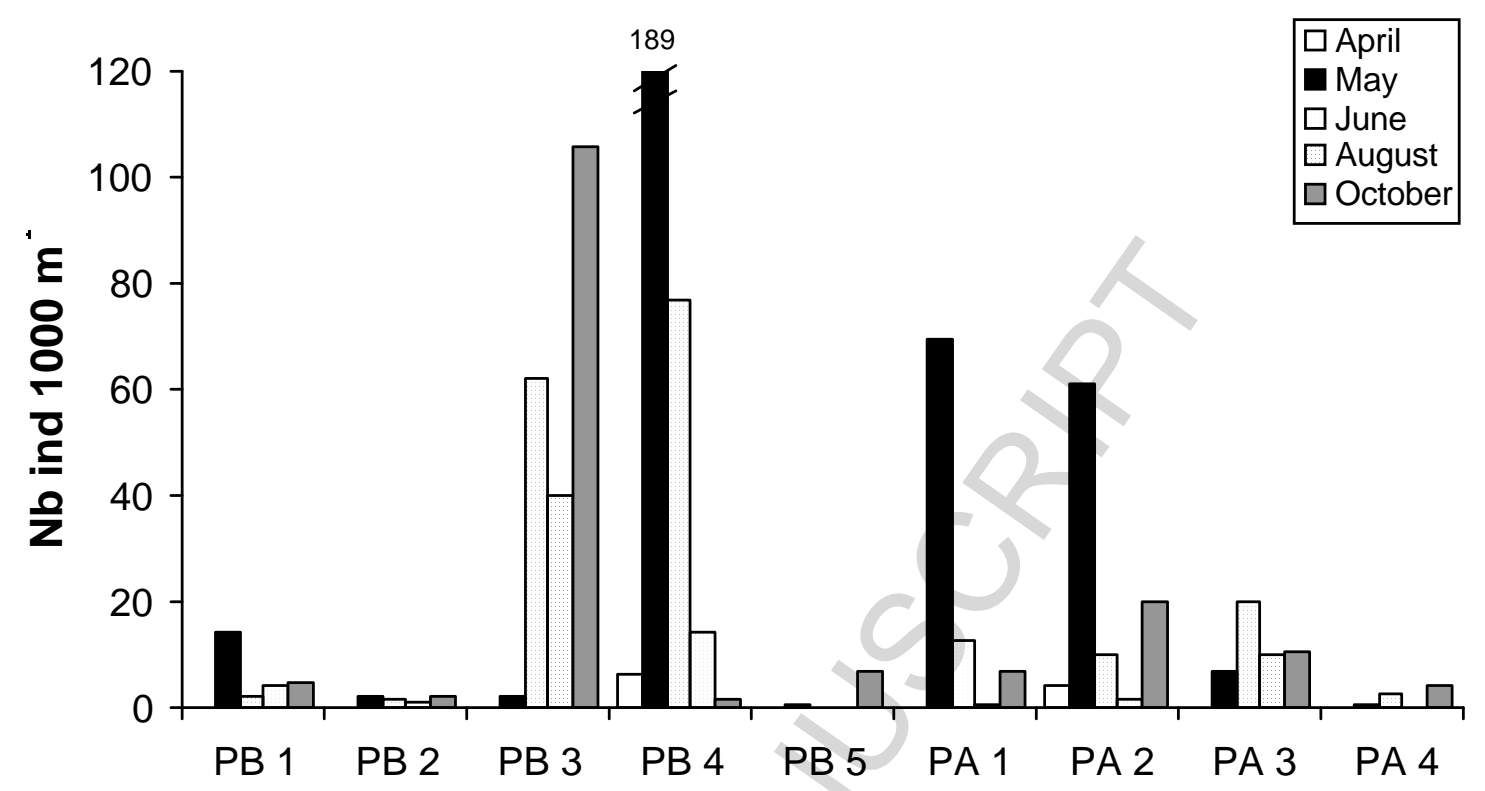

Fig 2. 
237

238

239

240

241

242

243

244

245

246

247

248

249

250

251

252

253

254

255

256

257

258

259

260
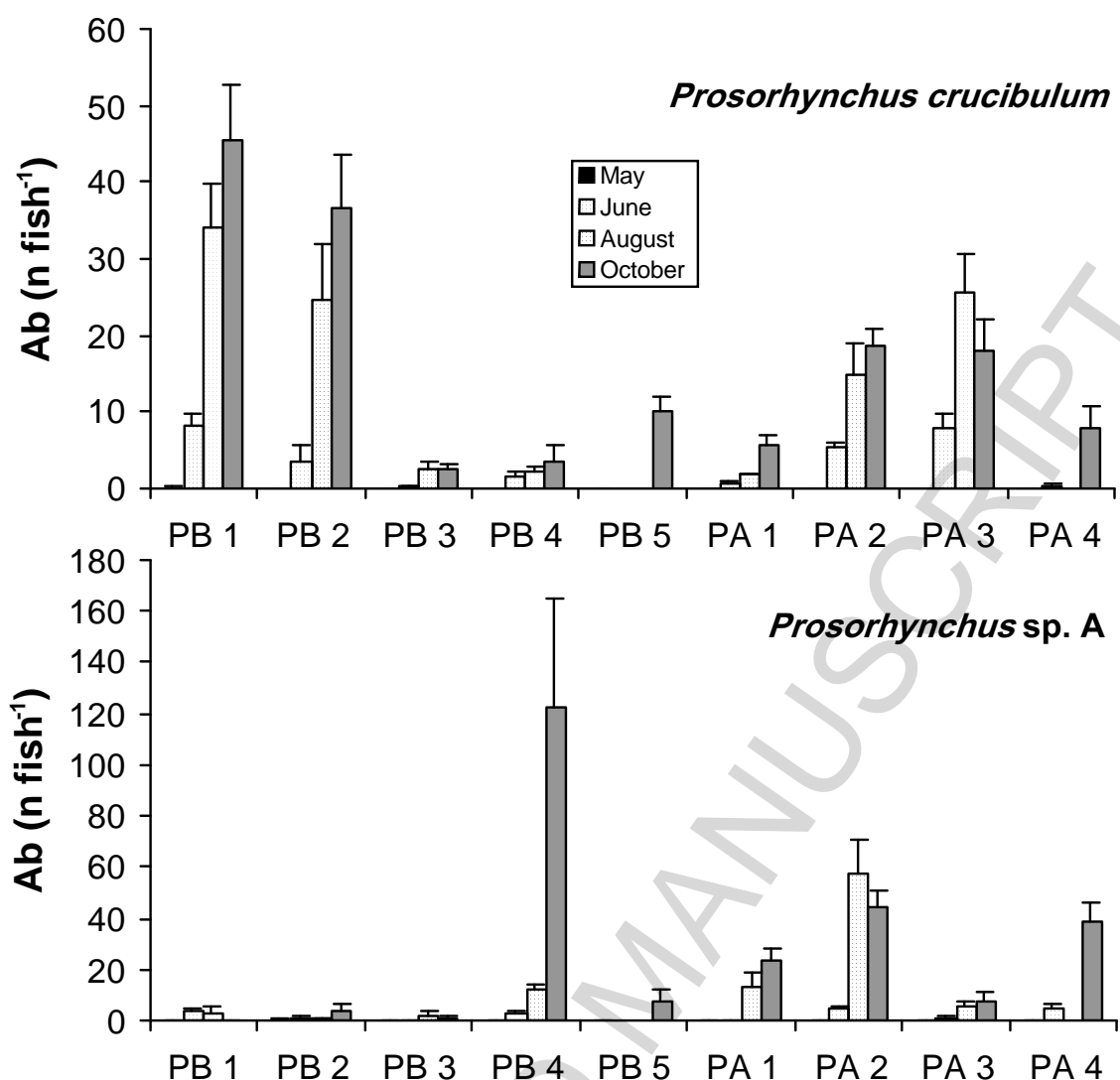

$\begin{array}{lllllllll}\text { PB } 1 & \text { PB } 2 & \text { PB } 3 & \text { PB } 4 & \text { PB } 5 & \text { PA } 1 & \text { PA } 2 & \text { PA } 3 & \text { PA } 4\end{array}$

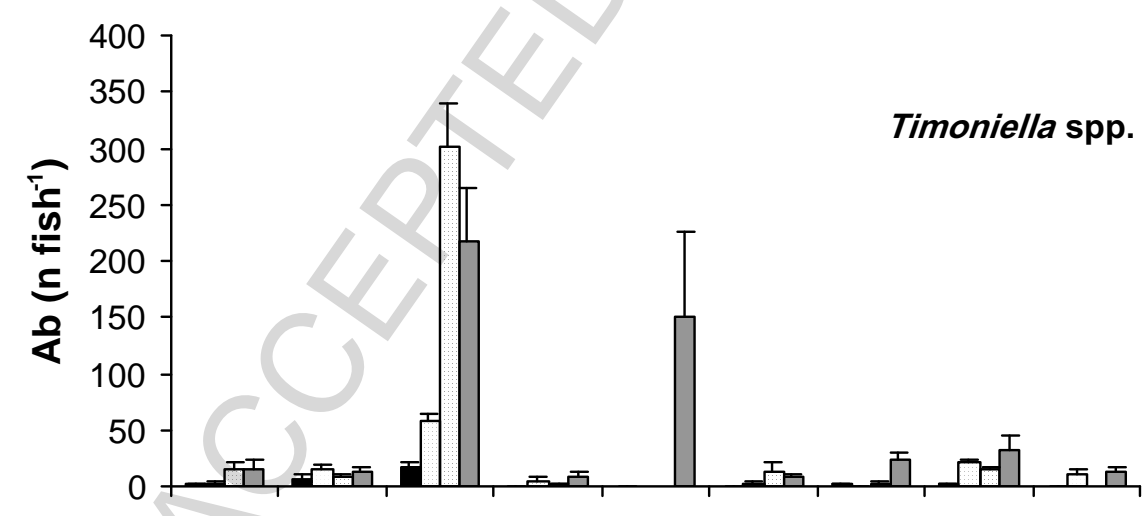

$\begin{array}{lllllllll}\text { PB } 1 & \text { PB } 2 & \text { PB } 3 & \text { PB } 4 & \text { PB } 5 & \text { PA } 1 & \text { PA } 2 & \text { PA } 3 & \text { PA } 4\end{array}$

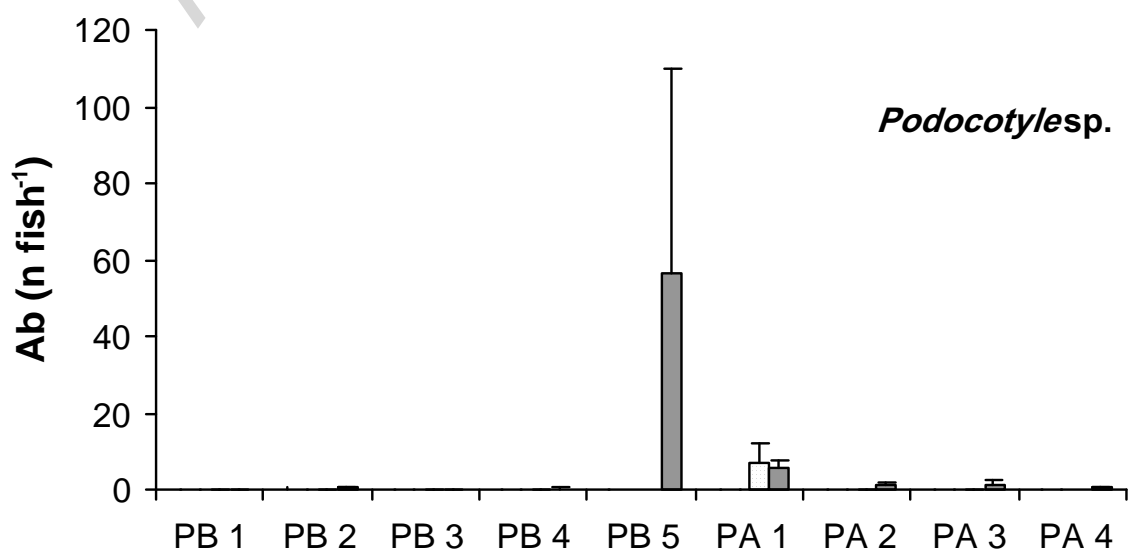

$261 \quad$ Fig 3. 


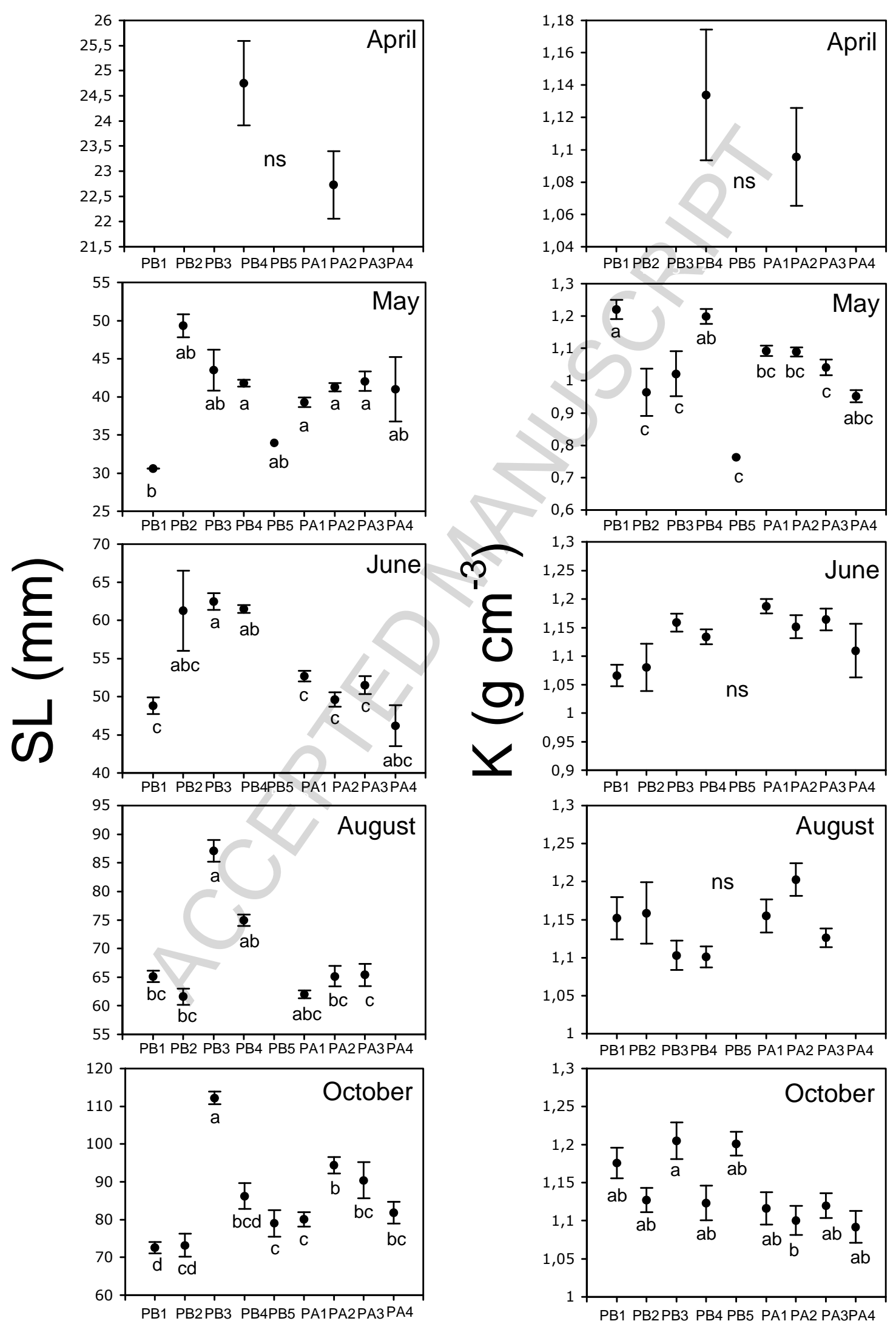

$264 \quad$ Fig 4. 

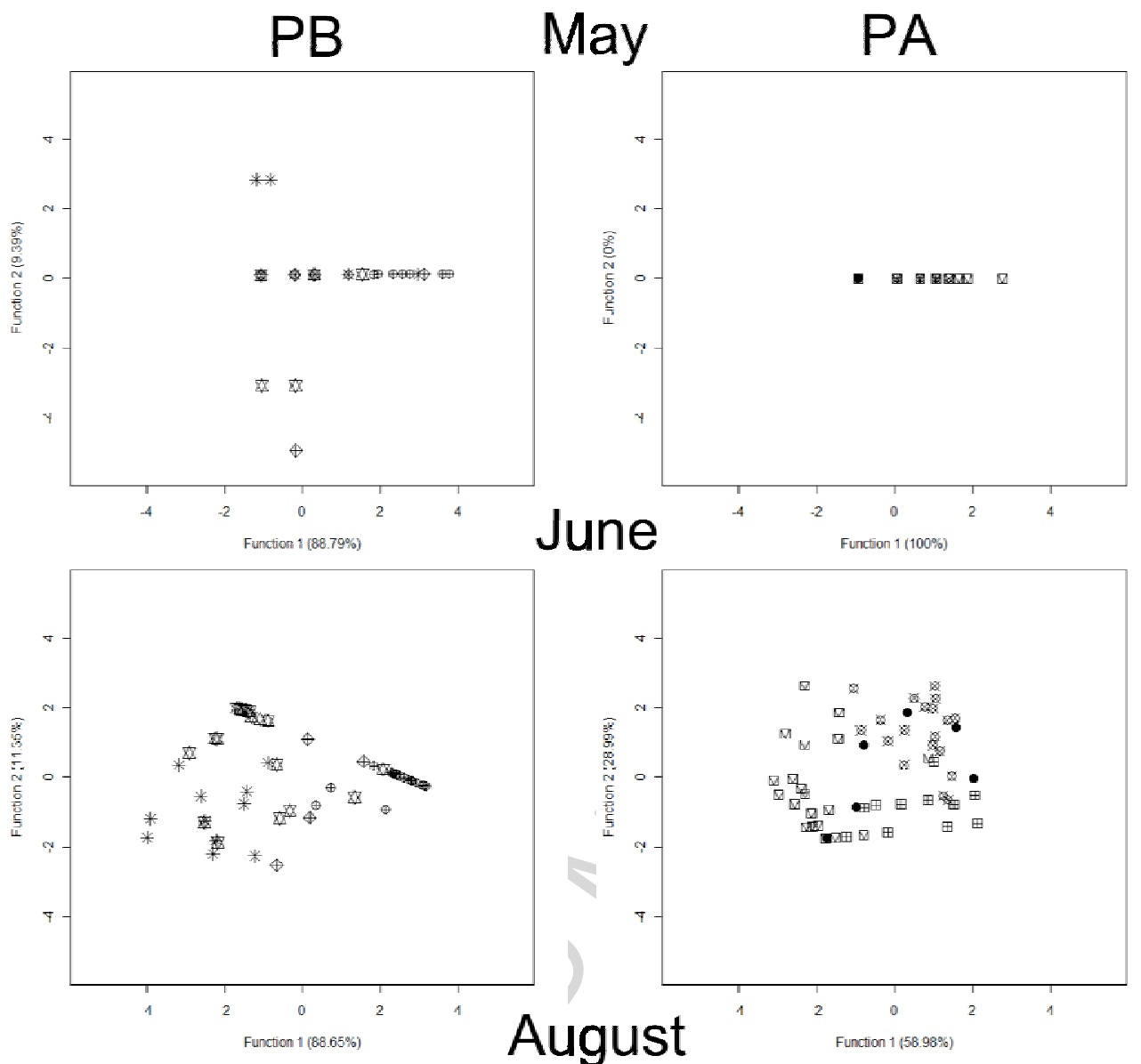

* PB1

$\$ \mathrm{~PB} 2$

๑PB3

XP4

⿴囗十A1

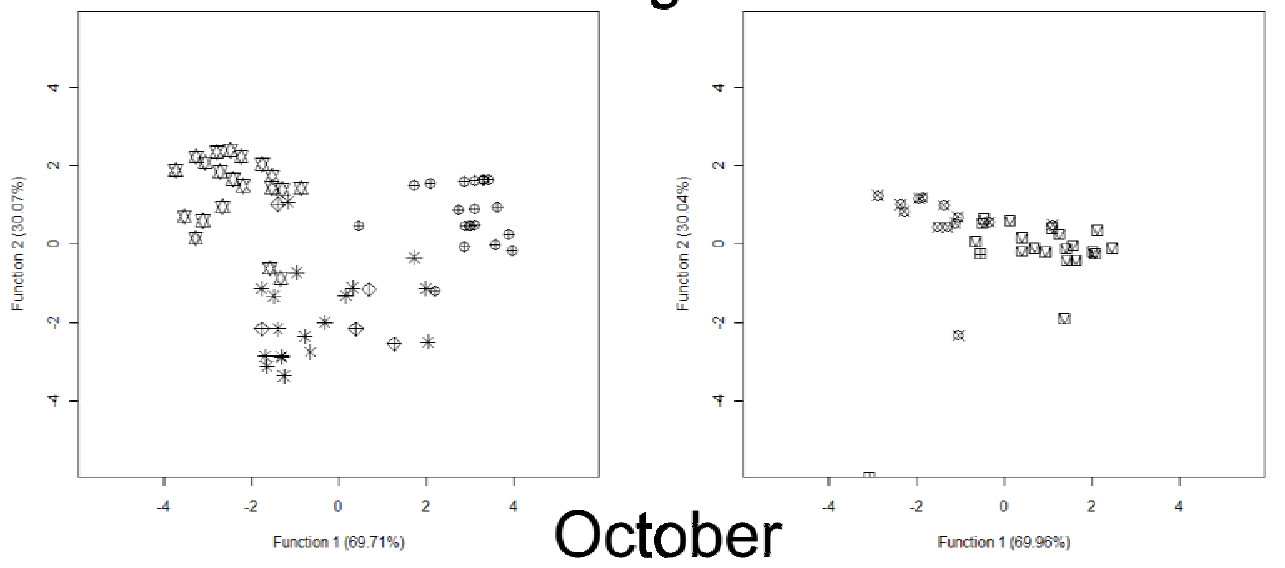

×A2

$\triangle P A 3$

- PB5

- PA4
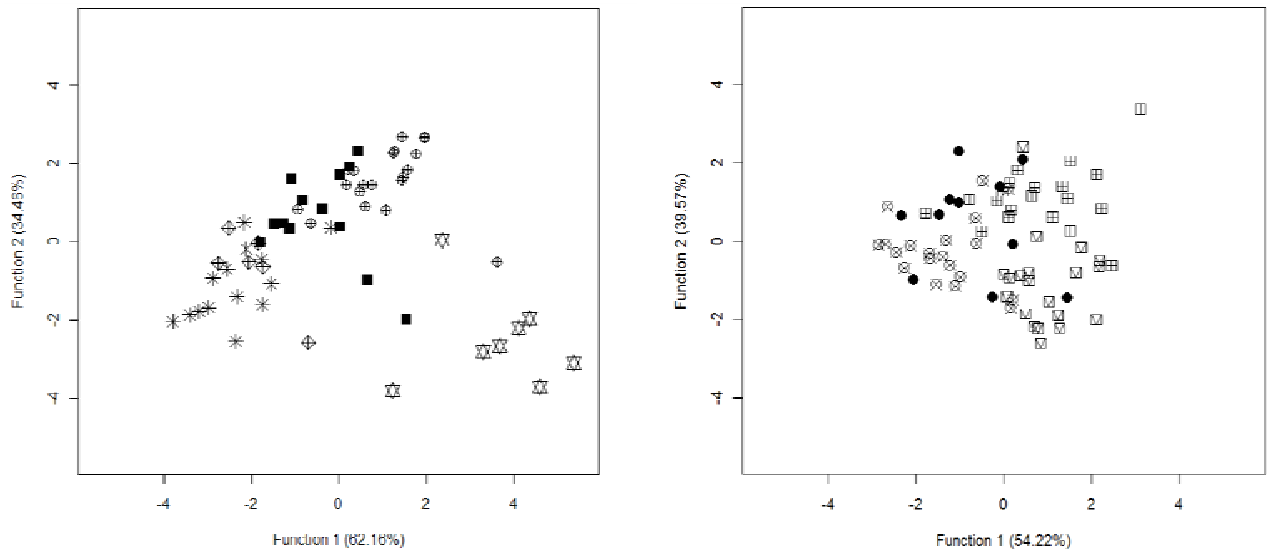

Fig. 5 